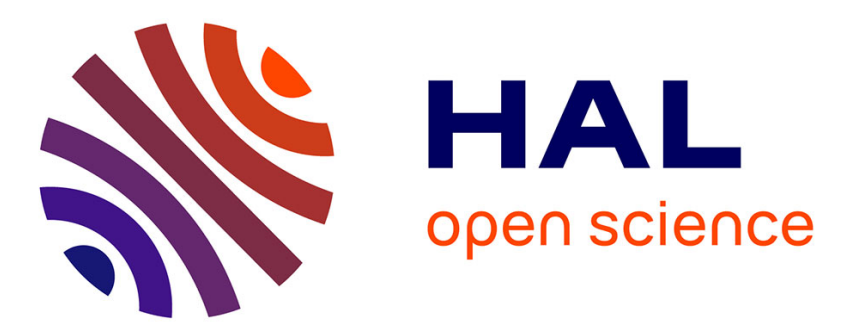

\title{
Dating the Tethyan Ocean in the Western Alps with radiolarite pebbles from synorogenic Oligocene molasse basins (southeast France)
}

Fabrice Cordey, Pierre Tricart, Stéphane Guillot, Stéphane Schwartz

\section{- To cite this version:}

Fabrice Cordey, Pierre Tricart, Stéphane Guillot, Stéphane Schwartz. Dating the Tethyan Ocean in the Western Alps with radiolarite pebbles from synorogenic Oligocene molasse basins (southeast France). Swiss Journal of Geosciences, 2012, 105 (1), pp.39-48. 10.1007/s00015-012-0090-8 . hal-02178343

\section{HAL Id: hal-02178343 \\ https://hal.science/hal-02178343}

Submitted on 30 Jun 2021

HAL is a multi-disciplinary open access archive for the deposit and dissemination of scientific research documents, whether they are published or not. The documents may come from teaching and research institutions in France or abroad, or from public or private research centers.
L'archive ouverte pluridisciplinaire HAL, est destinée au dépôt et à la diffusion de documents scientifiques de niveau recherche, publiés ou non, émanant des établissements d'enseignement et de recherche français ou étrangers, des laboratoires publics ou privés. 
Keywords: Western Alps, radiolarite, Jurassic, molasse, Oligocene, subduction wedge. 


\section{Abstract}

For the first time in the Western Alps, radiolarite pebbles collected from Tertiary foreland molasse conglomerates are treated for microfossil extraction and dated. Among fourty pebbles selected in the field, seven of them released diagnostic radiolarian assemblages ranging in age from Late Bajocian-Early Callovian to Middle Oxfordian-Early Tithonian. These ages overlap previous biochronological data obtained from in situ localities of the Schistes Lustrés Piemont zone of the French-Italian Alps and triple the number of diagnostic radiolarite samples known so far in this segment of the chain. The diagnostic pebbles are characterized by low grade metamorphism, showing that some eroded thrust-sheets from the oldest parts of the ocean escaped any tectonic burial during the Alpine convergence. Mixing of low and high-grade radiolarites, mafics and ultramafics pebbles implies that a variety of ocean-derived units was exposed. This tectonic scenario involves tight refolding and severe uplift of the Eocene subduction wedge in the Early Oligocene. 0

\section{Introduction}

The European Alps straddle the plate boundary between Europe and Africa where divergence dominated during most of Jurassic-Cretaceous times followed by convergence from the Late Cretaceous onwards (e.g. Tricart 1984). As a major witness to plate divergence, ophiolites derive from a small Tethyan ocean basin, the Alpine Tethys also named Liguria, LiguriaPiemont or Piemont-Liguria (review in Bernoulli and Jenkyns 2009, Lagabrielle 2009, Manatschal and Müntener 2009, de Graciansky et al. 2010). In the Western Alps, dismembered ophiolites and associated deep-sea sediments compose most of the Piemont 
zone (review in Schmid et al. 2004). They display subduction-related HP-LT metamorphic imprint evolving from blueschist facies in the outer Piemont units to eclogite facies in the inner ones (review in Bousquet et al. 2008). As an exception, the Chenaillet ophiolite (Fig. 1) escaped this metamorphism, suggesting that it derived from an obducted slab of oceanic lithosphere (Mével et al. 1978, Barfety et al. 1995 with references therein). (1) opening to closure remains a major challenge among Alpine geologists. Two difficulties remained for a long time: the rarity of radiometric ages from ophiolites and the missing fossil record due to metamorphism and/or erosion of sedimentary covers. Fortunately, some of the Western Alps units closely resemble the unmetamorphic ophiolite thrust sheets of the Northern Apennines which suggest that Tethyan ocean spreading occurred during the MiddleLate Jurassic and possibly the Early Cretaceous (e.g. Lemoine et al. 1970, de Graciansky et al. 2010). Most modern reconstructions for the Western Alpine ocean derive from Marcel Lemoine’s sketches of the early 1980’s. They show the Alpine Tethys and the Central Atlantic as twin oceans for their initial opening and spreading (e.g. Lemoine 1983). On the Tethyan European paleomargin, the transgressive units and their fossil record exposed in the Briançonnais domain document the breakup unconformity (Lemoine et al. 1986) and provide a Middle Jurassic age (Late Bathonian) for the timing of initial opening of the nearby ocean (Lemoine et al. 2000, Bill et al. 2001).

A significant improvement came with the successive discovery and dating of three radiolarite supraophiolitic localities: (1) the Cascavelier Peak near Saint-Véran in Southern Queyras (De Wever and Caby 1981, De Wever and Baumgartner 1995), (2) the Traversiera massif near the French-Italian border in the upper Ubaye valley (Schaaf et al. 1985, De Wever 
et al. 1987, De Wever et Baumgartner 1995), and (3) more recently the Rocher de la Perdrix in the Montgenèvre massif, located structurally below the Chenaillet ophiolite s.s. (Cordey and Bailly 2007). In these three sites (Fig. 1), radiolarian faunas are preserved in lowtemperature blueschist-bearing metacherts at the front of the Piemont "Schistes lustrés” complex (Gidon et al. 1994; Tricart et al. 2003). These three fossil localities directly argue for an ocean opening during a period straddling the Middle and Late Jurassic times (Cordey and Bailly 2007).

82

3

In order to improve our knowledge of the Alpine ocean history, we explored the potential of synorogenic conglomerates derived from the erosion of oceanic thrust sheets building the Alpine wedge. Rüst (1885) was the first to describe Jurassic radiolarians from chert pebbles of western Switzerland molasses, but microfossil chemical extractions were not yet applied at the time. A more recent interest for syn- or postorogenic clastics was developed in the North American Cordillera on the well-known “chert pebble conglomerates” associated with Mesozoic ocean sutures and accreted terranes (Seiders and Blome 1984; Cordey 1992a, 1992b, 1998). In this Alpine study, our objectives were not only to find new dates related to the Jurassic opening of Tethys but also to document ocean closure and subsequent mountain building during Early Oligocene time.

\section{The Oligocene polygenic conglomerates in the foreland of the southern Western Alps}

Within the Paleogene molasses of the Western Alps external zone, our investigation focused on the French Subalpine chains located to the south of the Pelvoux massif (Ford et al. 1999, Ford and Lickorish 2004). In this region, Early Oligocene intra-orogenic basins (Fig. 2) 
100

101

102

103

104

105

106

contain conglomerates known for their ocean-derived pebbles (Termier 1895 in Gubler 1958, Boussac 1912) such as fragments of mafics and ultramafics rocks as well as radiolarian chert (Ferry et al. 2005). In the field, these radiolarite pebbles are easily recognizable by their dark red colour (Fig. 3). They represent the “exotic” pebbles par excellence, occupying a privileged position in the Alpine literature as symbols of a "Penninic" signature, the Swiss term to describe the internal Alpine zones. The Early Oligocene molasses are preserved within small basins in the foreland of the Paleogene Alpine accretionary wedge (e.g. Sissingh 2001) and were fed by clastic sediments derived from the erosion of uplifting Briançonnais and Piemont zones (Morag et al. 2008; Bernet and Tricart 2011). Initially, our main target was the Barrême basin, a small and well-studied valley located to the east of Digne thrust (de Graciansky 1972, Artoni and Meckel 1998, Evans and Elliott 1999). A second site was found farther north in the "Petit Buëch” valley near Montmaur (Fig. 1) where tectonically pinched molasses named "Nagelfluh" correspond to the southward extension of the Devoluy basin (Gidon 1971, Meckel et al. 1996).

(1) 
124 Pebbles faunal contents and ages are presented in Table 1. Key radiolarian taxa are illustrated

125 in Fig. 4. We use the standard Tethyan radiolarian zonation of Baumgartner et al. (1995)

126 based on Unitary Associations (UAZ) as well as complementary data from O’Dogherty et al.

127 (2006). The "age of a pebble” refers here to the age of the source radiolarite bed, not the age

128 of formation or deposition of the pebble.

129

130 Biochronology and ages are based on the following radiolarian occurrences:

131 - 7057-3: the assemblage contains Archeospongoprunum cf. imlayi Pessagno,

132 Orbiculiformella sp., Stichocapsa robusta Matsuoka, and Stichocapsa sp.. The age is

133 provided by the occurrence of $S$. robusta Matsuoka known from UAZ 5 to UAZ 7

134 corresponding to the Late Bajocian-Early Callovian interval.

135 - 7057-8 comprises Cinguloturris carpatica Dumitrica, Praeconocaryomma sp., Stichocapsa

136 aff. robusta Matsuoka (Fig. 4, $n^{\circ} 18$ ) and ?Stichomitra sp. (Fig. 4, $n^{\circ} 14$ ). This assemblage is

137 assigned to biozones UAZ 7-11 of Late Bathonian-Early Callovian to Late Kimmeridgian-

138 Early Tithonian age.

139 - 7057-14 contains Acaeniotyle diaphorogona Foreman (Fig. 4, n 26), Archeodictyomitra

140 apiarum (Rüst), Archeodictyomitra sp. (Fig. 4, n 7), Cinguloturris carpatica Dumitrica (Fig.

141 4, n 4), Emiluvia ordinaria Ozvoldova, Mirifusus sp. (Fig. 4, n 3), Parahsuum carpathicum

142 Widz \& De Wever (Fig. 4, n 11), ?Parvicingula mashitaensis Mizutani (Fig. 4, $\mathrm{n}^{\circ}$ 10),

143 Podobursa cf. spinosa Ozvoldova (Fig. 4, n²4), Protunuma sp. (Fig. 4, n 13),

144 Pseudoeucyrtis sp. (Fig. 4, n 1), Zhamoidellum ovum Dumitrica (Fig. 4, n 17) and

145 Zhamoidellum sp. (Fig. 4, $\mathrm{n}^{\circ}$ 19). This assemblage is attributed to biozones UAZ 9-11 of

146 Middle Oxfordian to Early Tithonian age.

147 - 7057-15 contains a peculiar association which is not reported in Baumgartner et al. (1995)

148 biozonation but is documented by O’Dogherty et al. (2006): Yaocapsa sp. (Fig. 4, n 12), 
150 Dumitrica (Fig. 4, $\mathrm{n}^{\circ}$ 16) and Zhamoidellum cf. calamin O'Dogherty, Gorican \& Dumitrica

151 (Fig. 4, n 22). This assemblage is tentatively assigned to UAZ 6-7 (O’Dogherty et al. 2006).

152 - 7057-20 contains Archeodictyomitra apiarum (Rüst), Bernoullius cf. dicera Baumgartner

153 (Fig. 4, n 29), Praeconocaryomma sp. and Stichocapsa sp.. It provides a Middle Callovian-

154 Early Kimmeridgian age (UAZ 8-10). As the occurrence of species B. dicera Baumgartner is

155 uncertain, the upper age limit of this association is tentative.

156 - 7057-22: correlation to biozone UAZ 7 of Late Bathonian-Early Callovian age is provided

157 by co-occurrence of Cinguloturris carpatica Dumitrica (Fig. 4, n 4) and Pseudoristola

158 tsunoensis (Aita) (Fig. 4, $\mathrm{n}^{\circ}$ 22). Other radiolarians compatible with this age determination are

159 Williriedellum sp. 1 (Fig. 4, $\mathrm{n}^{\circ}$ 23) only documented in Les Gets nappe along with

160 morphotypes from UAZ 6 and 7 (O’Dogherty et al. 2006) and Archeospongoprunum elegans

161 Wu (Fig. 4, $n^{\circ}$ 2) also known in this time interval. Other morphotypes present in 7057-14 are

162 Arcanicapsa cf. leiostraca (Foreman) (Fig. 4, n²1), Archeodictyomitra sp. (Fig. 4, n 8),

163 Cinguloturris sp. (Fig. 4, $\mathrm{n}^{\circ}$ 5), Emiluvia cf. chica Foreman (Fig. 4, $\mathrm{n}^{\circ}$ 27), ?Fultocapsa sp.

164 (Fig. 4, $n^{\circ}$ 25), Homoeoparonaella argolidensis Baumgartner (Fig. 4, n 28), Mirifusus sp.,

165 Pseudodictyomitrella cf. tuscanica Chiari, Cortese \& Marcucci (Fig. 4, n 15), and Tritrabs

166 rhododactylus Baumgartner (Fig. 4, n 30).

167 - 7064-E1 contains Archeodictyomitra apiarum (Aita) (Fig. 4, n 4), Archeospongoprunum cf.

168 imlayi Pessagno (Fig. 4, $\mathrm{n}^{\circ}$ 3) and Cinguloturris carpatica Dumitrica (Fig. 4, $\mathrm{n}^{\circ}$ 4). This

169 assemblage is assigned to UAZ 8-11 of Middle Callovian to Early Tithonian age.

171 In summary:

172 1. Our chert pebbles range in age from Late Bajocian-Early Callovian (UAZ 5-7) to Middle

173 Oxfordian-Early Tithonian (UAZ 8-11). 
174 2. The oldest pebble could be as old as Late Bajocian (base of UAZ 5) but also as young as

175 Early Callovian (top of UAZ 7).

176 3. The youngest pebble could be as old as Middle Oxfordian (7057-14) and as young as Early 177 Tithonian (7057-14 or 7064-E1).

178 4. Three pebbles are Middle Jurassic in age. Among them, 7057-22 is restricted to UAZ 7 of 179 Late Bathonian-Early Callovian age. The two others 7057-3 and -15 are possibly of the same 180 age but could also be younger (UAZ 5-7 and UAZ 6-7 respectively).

181 5. Only one pebble (7057-14) is with certainty Late Jurassic in age. The three remaining 182 pebbles are either Middle or Late Jurassic (7057-8, 7057-20, and 7064-E1).

183

184

185

186

187

188

189

190

191

192

193

194

195

196

197

\section{Comparisons with previous radiolarian localities of the Piemont Schistes Lustrés zone}

\subsection{Biochronology}

As mentioned previously, only three localities of supraophiolitic radiolarites are dated so far in the Schistes Lustrés complex of the French-Italian Alps. They range in age from Middle Bathonian to Middle-Late Oxfordian:

1. the Cascavelier Peak radiolarite near Saint-Véran was originally dated as Late OxfordianMiddle Kimmeridgian (De Wever and Caby 1981). This age was later revised to the Middle or Late Oxfordian (UAZ 9) (De Wever and Baumgartner 1995).

2. the Traversiera massif locality was originally found by R. Polino (Torino), with radiolarians occurring in phosphate nodules at the base of the sedimentary cover of the ophiolite (Y. Lagabrielle, pers. com. 2006). It was dated as Late Oxfordian-Early 
198 Kimmeridgian (Schaaf et al. 1985), an age later revised as Late Bathonian-Early Callovian

199 (UAZ 7) (De Wever et al. 1987; De Wever et Baumgartner 1995).

200 3. the "Rocher de la Perdrix" radiolarites from the Chenaillet massif near Montgenèvre are 201 exposed in the Lago Nero-Replatte thrust sheet located structurally beneath the Chenaillet 202 ophiolite thrust sheet s.s.. It was tentatively assigned to UAZ 6 of Middle Bathonian age. It 203 could be the oldest radiolarite exposure of the Piemont zone (Cordey and Bailly 2007).

In comparing our results with these biochronological data, we find that the ages of radiolarite pebbles overlap almost entirely the age range known from in situ Piemont Schistes Lustrés radiolarite localities. Our results also lead to the following observations:

208 1. In our sampling, biozone UAZ 7 seems well represented in 2 pebbles, possibly 4. It matches the age established in the Traversiera massif (Late Bathonian-Early Callovian). 2. The occurrence of biozone UAZ 6 known at the Chenaillet is not confirmed but could be 211 present in 2 of the 7 pebbles.

3. Our youngest pebble could be coeval to the Pic Cascavelier locality of Middle-Late Oxfordian age (UAZ 9) but could also be younger (Kimmeridgian or Early Tithonian).

Some radiolarian morphotypes present in our pebbles were not reported before in the Piemont 218 Schistes Lustrés in situ radiolarites. The Pic Cascavelier locality (UAZ 7) has an assemblage 219 of sixteen species in which only Homoeoparonaella argolidensis Baumgartner occurs in one pebble (7057-22). The St-Véran section (UAZ 9) comprises nineteen species in which only Acaeniotyle diaphorogona Foreman and potentially Bernoullius dicera (Baumgartner) are 222 present in our assemblages. Finally, the Rocher de la Perdrix locality has only 5 morphotypes 
with 2 species of the genus Kilinora which does not occur elsewhere. Overall, our pebbles seem richer in nassellarians, including morphotypes of Cinguloturris, Fultocapsa, Protunuma, Pseudodictyomitrella, Pseudoristola, Pseudoeucyrtis, Stichocapsa, Yaocapsa and Zhamoidellum which were not reported in other localities of the Piemont Schistes Lustrés zone (Bill et al. 2001). On one hand, these discrepancies may not be paleontologically significant as they could result from taphonomical biases. On the other hand, they could suggest that radiolarite beds stored as pebbles in molasse conglomerates have no in situ equivalents, or that these equivalents have been entirely destroyed or metamorphosed. We have presently no argument for preferring one of these hypotheses.

\section{Discussion and conclusions}

\subsection{The Alpine Tethys birth and spreading scenario}

The oldest radiolarite sample documented in our study is Late Bajocian or Early Callovian in age. If we considers that in situ radiolarites of the Western Alps are associated with ophiolite basements, this age remains compatible with the classical scenario of synchronous opening for both the Central Atlantic and the Alpine Tethys in the Middle Jurassic (Lemoine et al. 2000, Bill et al. 2001, Cordey and Bailly 2007, de Graciansky et al. 2010). However we do not know if the sampled molasses contain older oceanic remnants. In the outer Piemont zone, the three thrust-sheets bearing diagnostic supraophiolitic radiolarites are imbricated with thrust-sheets derived from the European distal margin (Caby et al. 1971, Tricart et al. 2003). The simplest hypothesis is that our pebbles result from the erosion of ophiolite-bearing thrustsheets of a similar Piemont paleogeographic origin, i.e. the part of the ocean located at the 
foot of the European margin. However, one cannot rules out a source in one or several now

249 entirely eroded units that originated from the other side of the ocean at the foot of the African margin (Adria).

With the contribution of these fossiliferous pebbles, the number of radiolarites dated

253 so far in the Piemont zone of the Western Alps increases from 3 to 10. If the occurrence of Kimmeridgian or Tithonian cherts was confirmed by future sampling, it would extend the time span represented in these deep-sea sediments from 16 to 20 Myr. For an ocean with a very low spreading rate of $\sim 2 \mathrm{~cm} /$ year as expected for the Alpine Tethys (Lagabrielle and Cannat 1990, Lagabrielle and Lemoine 1997, Lagabrielle 2009, Manatschal and Müntener 2009), this time span could correspond to $400 \mathrm{~km}$ in width. Of course this estimate is to be considered with caution, as pebbles could come from any level of an original radiolarite succession resting on a slightly older crust.

We do not bring any evidence for the occurrence of radiolarite sedimentation in the Early Cretaceous and consequently an even wider oceanic domain. However most Tethyan basin facies grade into pelagic limestones or shale/limestone alternation in the Late Tithonian (Bill et al. 2001). All direct and indirect fossiliferous elements of the ocean found in ophiolite covers and molasses are from the oldest parts of this domain, corresponding to remnants of the so-called "narrow ocean” stage. As already observed elsewhere in the Alpine-Apennine domain, radiolarite units are Middle and Late Jurassic without any evidence of Cretaceous chert sedimentation (Bill et al. 2001). Apart from the Balma and Chiavenna units in the Valais oceanic domain (93 Ma U/Pb ages; Liati and Froitzheim 2006), all other radiometric ages overlap the age of radiolarian cherts (Manatschal and Müntener 2009). In the hypothesis of ongoing Cretaceous rifting, elements of a younger and more axial part of this ocean remain to 
273 be identified. If such elements are no longer exposed, they could remain hidden at depth.

274 They could also can have been eroded after exhumation. If this is the case, further

275 investigation on foreland detrital formations is needed. However, the most probable

276 explanation is that during the Cretaceous, the Alpine Tethyan ocean was no more active and

277 the oceanic spreading was mostly accommodated in the Central Atlantic to the west and the

278 Neotethys to the east.

279

280

5.2. The Alpine orogenic wedge building scenario

281

282

During Early Oligocene times, the present-day Alpine internal zones inherited part of the

Eocene subduction-related accretionary wedge that had just undergone syncollisional

polyphase shortening (Tricart et al. 2006, Morag et al. 2008, Bernet and Tricart 2011). The

erosion of the new-born mountain range with exposed margin- and ocean-derived thrust

sheets fed rather abruptly the foreland molasses which show a great variety of lithologies, not

only radiolarites but also magmatic pebbles such as basalts and gabbros with greenschist to

blueschist facies, as well as serpentinized peridotites with blueschist to eclogite facies (de

Gracianski et al. 1971, Schwartz et al., in press). As this foreland was progressively affected

by folding and forethrusting, Oligocene molasse basins born along the Alpine front evolved as external zone : see review in Ford et al. 2006).

Although in situ fossiliferous radiolarian cherts of the outer Piemont zone underwent

295 high greenschist or blueschist facies metamorphism, our study shows that some eroded

296 radiolarite units buried as molasse pebbles experienced low P-T conditions. This is supported

297 by the following observations: 1/ low silica recrystallization of pebbles's radiolarite matrices, 
2/ absence of phengites in the pebbles microfacies; these white micas are commonly observed

299 in the HP blueschist siliceous facies of the Piemont zone, 3/ fair preservation of radiolarian

300 microfossils. It is also noteworthy that Mesozoic radiolarite pebbles of the Subalpine molasse

301 display much higher rates of microfossil recovery than in situ Mesozoic radiolarites of the

302 Piemont zone. Interestingly, the same low-grade metamorphism characterizes the chert

303 pebbles extracted from synorogenic conglomerates derived from the Mesozoic accretionary

304 complexes of western North America (Seiders and Blome 1984; Cordey, 1992a, b, Cordey

305 1998). There, some radiolarite pebbles have revealed the existence of ocean units whose

306 equivalent correlatives have never never found in situ (Cordey 1998). Our study suggests that

307 it is also the case in the Alps.

308

The occurrence of low-grade radiolarite pebbles indicate that some eroded thrustsheets originating from the oldest parts of the ocean escaped any serious tectonic burial during

311 the Alpine convergence (Fig. 5). The 20 Myr potential age range represented by our

312 radiolarite pebbles does not favor a single source. However, we do not know if these

313 radiolarites derived from the European side or from both sides of the ocean spreading-ridge.

314 Yet they show that by $30 \mathrm{Ma}$, the Alpine wedge had probably sampled the entire oceanic

315 sediments accreted at very contrasted structural levels in the accretionary wedge. The question

316 whether there is a link between the paleogeographic European or African origin of these

317 remnants and their structural history remains open. Future models for the building of the

318 Alpine wedge during early convergence will have to test the processes of a selective tectonic

319 sampling of these paleogeographic realms during accretion. 
323 We thank Pierre-Charles de Graciansky (Paris) and Peter O. Baumgartner (Lausanne) for their 324 thorough and insightful reviews. This work was supported by the CNRS-UMR 5276 and the 325 ANR program “ERD-Alps” (Erosion and Relief Development in the western Alps). Chert 326 pebbles were processed in the radiolarian extraction laboratory of Université Lyon 1 (CNRS327 UMR 5276). We also thank Arlette Armand (Lyon) for SEM assistance.

\section{References}

Artoni, A., and Meckel, L., D., III (1998). History and deformation rates of a thrust sheet top basin: the Barrême basin, western Alps, SE France. Geological Society Special Publication, 134, p. 213-237.

Barféty, J. C., Lemoine, M., Graciansky, P. C. de, Tricart, P., and Mercier, D. (1995). Notice explicative, Carte géol. France (1/50 000), feuille Briançon (823), Orléans. Bureau de Recherches Géologiques et Minières, 180 p.. Geological map by J.C. Barféty, M. Lemoine, D.

340 Baumgartner, P.O., Bartolini, A., Carter, E.S., Conti, M., Cortese, G., Danelian, T., De 341 Wever, P., Dumitrica, P., Dumitrica-Jud, R., Gorican, S., Guex, J., Hull, D.M., Kito, N., 342 Marcucci, M., Matsuoka, A., Murchey, B., O’Dogherty, L., Savary, J., Vishnevskaya, V., 343 Widz, D., Yao, A. (1995). Middle Jurassic to Early Cretaceous radiolarian biochronology of

344 Tethys based on unitary associations, in: Baumgartner, P.O., et al. (Eds.), Middle Jurassic to 
Lower Cretaceous Radiolaria of Tethys: Occurrences, systematics, biochronology. Mémoires

346 de Géologie, 23, Lausanne, 1013-1043.

347

348 Bernet, M., and Tricart, P. (2011). The Oligocene orogenic pulse in the Southern Penninic

349 Arc (Western Alps): structural, sedimentary and thermochronological constraints. Bulletin de 350 la Société Géologique de France, 182, 25-36. doi: 10.2113/gssgfbull.182.1.25.

351

352 Bernoulli, D., and Jenkyns, H. (2009). Ancient oceans and continental margins of the Alpine 353 Mediterranean Tethys: deciphering clues from Mesozoic pelagic sediments and ophiolites. 354 Sedimentology, 56, 149-190.

355

356 Bill, M., O’Dogherty, L., Guex, J., Baumgartner, P.O., and Masson, H. (2001). Radiolarite 357 ages in Alpine-Mediterranean ophiolites. Constraints on the oceanic spreading and the 358 Tethys-Atlantic connection. Geological Society of America Bulletin, 113, 129-43.

359

360 Bousquet, R., Oberhänsli, R., Goffé, B., Wiederkehr, M., Koller, F., Schmid, S. M., Schuster, 361 R., Engi, M., Berger, A., and Martinotti, G. (2008). Metamorphism of metasediments at the 362 scale of an orogen: a key to the Tertiary geodynamic evolution of the Alps. In Siegesmund, 363 S., Fügenschuh, B., and Froitzheim, N. (Eds.), Tectonic Aspects of the Alpine-Dinaride364 Carpathian System (pp. 393-411). The Geological Society of London.

366 Boussac, J. (1912). Etudes statigraphiques sur le Nummulitique alpin. Mémoire explicatif de 367 la carte géologique détaillée de la France, 662 pp. 
Caby, R., Michard, A., and Tricart, P. (1971). Découverte d’une brèche polygénique à

370 éléments granitoïdes dans les ophiolites métamorphiques piémontaises (Schistes lustrés du

371 Queyras, Alpes françaises). Comptes Rendus de l’Académie des Sciences Paris, 273, sér. D, 372 999-1002.

373

374 Chauveau, J. C., and Lemoine, M. (1961). Contribution à l'étude géologique du synclinal 375 tertiaire de Barrême (moitié nord). Bulletin de la Carte géologique de France, 264, 147-178. 376

377 Cordey, F. (1992a). Radiolarians and Terrane Analysis in the Canadian Cordillera: the "clastic 378 approach". In Aitchison, J., and Murchey, B. (Eds.), The significance and application of 379 Radiolaria to Terrane Analysis. Palaeogeography Palaeoclimatology Palaeoecology, 96, 155380159.

381

382 Cordey, F. (1992b). Radiolarian ages from chert pebbles of the Tantalus Formation, Carmacks 383 area, Yukon Territory. Geological Survey of Canada Paper 92-1E, 53-59.

384

385 Cordey, F. (1998). Radiolaires des complexes d'accrétion cordillérains (210pp.). Geological 386 Survey of Canada Bulletin 509.

387

388 Cordey, F., and Bailly, A. (2007). Alpine ocean seafloor spreading and onset of pelagic 389 sedimentation: new radiolarian data from the Chenaillet-Montgenèvre ophiolite (French390 Italian Alps). Geodinamica Acta, 20, 131-138.

391 
392

393

394

395

396

397

398

399

400

401

402

403

404

405

406

407

408

409

410

411

412

413

414

415

416

De Wever, P., and Caby, R. (1981). Datation de la base des Schistes lustrés postophiolitiques par des radiolaires (Oxfordien supérieur-Kimméridgien moyen) dans les Alpes Cottiennes (Saint-Véran, France). Comptes Rendus de l'Académie des Sciences Paris, 292, 467-472.

De Wever, P., and Baumgartner, P.O. (1995). Radiolarians from the base of the supraophiolitic Schistes Lustrés Formation in the Alps (Saint-Véran, France and Traversiera Massif, Italy). In Baumgartner, P.O., et al. (Eds.), Middle Jurassic to Lower Cretaceous Radiolaria of Tethys: occurrences, systematics, biochronology. Mémoires de Géologie, 23, Lausanne, 725-730.

De Wever, P., Danelian, T., Durand-Delga, M., Cordey, F., and Kito, N. (1987). Datations des radiolarites post-ophiolitiques de Corse alpine à l'aide des Radiolaires. Comptes Rendus de l’Académie des Sciences Paris, 305, 893-900.

Evans, M. J., and Elliott, T. (1999). Evolution of a thrust-sheet-top basin: the Tertiary

Barrême basin, Alpes de Haute Provence, France. Geological Society of America Bulletin, $111,1617-1643$.

Ferry, S., Tremblay, S., Guiraud, M. and Cordey, F. (2005). Les molasses rouges paléogènes du bassin subalpin français. Corrélations avec le bassin helvétique. ASF Association Sédimentologie France, Octobre 2005 (abstract).

Ford, M., and Lickorish, W. H. (2004). Foreland basin evolution around the western Alpine arc. In Joseph, P., and Lomas, S. (Eds.). Geological Society Special Publication, 39-63. 
417 Ford, M., Lickorish, W. H., and Kusznir, N. J. (1999). Tertiary foreland sedimentation in the

418 Southern Subalpine Chains, SE France: A geodynamic appraisal. Basin Research, 11, 315419336.

420

421 Ford, M., Duchene, S., Gasquet, D., and Vanderhaeghe, O. (2006). Two-phase orogenic 422 convergence in the external and internal SW Alps. Journal of the Geological Society, 163, p. $423 \quad 815-826$.

424

425

Gidon, M. (1971). Gap, Geological Map of France 1:50 000. Bureau de Recherches

426 Géologiques et Minières.

427

428 Gidon, M., Kerckhove, C., Michard, A., Tricart, P., Gotteland, P., Gout, C., Leblanc, D., 429 Lefevre, R., Le Guernic, J., Mégard-Galli, J., and Michel-Noël, G. (1994). Aiguille de 430 Chambeyron, Geological Map of France 1:50 000. Bureau de Recherches Géologiques et 431 Minières.

432

433 Graciansky, P. C. de (1972). Le bassin tertiaire de Barrême (Alpes de Haute-Provence): 434 relations entre déformation et sédimentation; chronologie des plissements. Comptes Rendus 435 de l'Académie des Sciences, Paris, 275, 2825-2828.

436

437 Graciansky, P. C. de, Lemoine, M., and Saliot, P. (1971). Remarques sur la présence de 438 minéraux et de paragénèses du métamorphisme alpin dans les galets des conglomérats 439 oligocènes du synclinal de Barrême (Alpes de Haute-Provence). Comptes Rendus de 440 l'Académie des Sciences, Paris, 272, 3243-3245. 
442 Graciansky, P. C. de, Roberts, D. and Tricart, P. (2010). The Western Alps from rift to passive 443 margin to orogenic belt : an integrated geosciences overview (432 pp.). Elsevier.

444

445 Gubler, Y. (1958). Etude critique des sources du matériel constituant certaines séries dans le 446 Tertiaire des Alpes françaises du Sud: formations détritiques de Barrême, Flysch "Grés 447 d'Annot". Eclogae Geologicae Helvetiae, 51, 942-977.

448

449

Lagabrielle, Y. (2009). Mantle exhumation and lithospheric spreading: an historical 450 perspective from investigations in the oceans and in the Alps-Appennines ophiolites. Italian 451 Journal of Geosciences, 128, 279-293.

452

453

Lagabrielle, Y. and Cannat, M. (1990). Alpine Jurassic ophiolites resemble the modern central 454 Atlantic basement. Geology, 18, 319-22.

455

Lagabrielle, Y. and Lemoine, M. (1997). Alpine, Corsican and Apennine ophiolites: the slow457 spreading ridge model. Comptes Rendus de l’Académie des Sciences, Paris, 325, sér. II, 909458 20.

459

Lemoine, M. (1983). Rifting and early drifting: Mesozoic Central Atlantic and Ligurian Tethys. Initial reports Deep Sea Drilling Project, US Government Printing Office,

462 Washington DC, 76, 885-895.

463

464

Lemoine, M., and Tricart, P. (1986). Les Schistes lustrés piémontais des Alpes occidentales: approche stratigraphique, structurale et sédimentologique. Eclogae Geologicae Helvetiae, 79, 271-94. 
468 Lemoine, M., Steen, D., and Vuagnat, M. (1970). Sur le problème stratigraphique des 469 ophiolites piémontaises et des roches sédimentaires associées: observations dans le massif de 470 Chabrière en Haute-Ubaye (Basses-Alpes, France). Archives des Sciences, Genève, 5, 44-59.

471

472 Lemoine, M., Bas, T., Arnaud-Vanneau, A., Arnaud, A., Dumont, T., Gidon, M., Bourbon, 473 M., Graciansky, P.-C. d., Rudkiewicz, J.-L., Mégard-Galli, J., and Tricart, P. (1986). The

474

475

476

477

478

479

480

481

482

483

484

485

486

487

488

489

490

491 continental margin of the Mesozoic Tethys in the Western Alps. Marine and Petroleum

Geology, 3, 179-199.

Lemoine, M., Graciansky, P.-C. de, and Tricart, P. (2000). De l'océan à la chaîne de montagnes: tectonique des plaques dans les Alpes (207 p.). Paris : Gordon and Breach Science.

Liati, A., and Froitzheim, N. (2006). Assessing the Valais ocean, Western Alps: U-Pb SHRIMP zircon geochronology of eclogite in the Balma unit, on top of the Monte Rosa nappe. European Journal of Mineralogy, 18, 299-308.

Manatschal, G., and Müntener, O., (2009). A type sequence across an ancient magma-poor ocean-continent transition: the example of the western Alpine Tethys ophiolites.

Tectonophysics, 437, 4-19.

Meckel, L., D., III, Ford, M., and Bernoulli, D. (1996). Tectonic and sedimentary evolution of the Dévoluy Basin, a remnant of the Tertiary western Alpine foreland basin, SE France.

Géologie de la France, 2, 3-26. 
493 Mevel, C., Caby, R., Kienast, J.-R. (1978). Lower amphibolite facies conditions in the oceanic

494

495

497

498

499

500

501

502

503

504

505

506

507

508

509

510

511

512

513

514

515

516

cruts: example of amphibolitized falser-gabbro and amphibolites from an alpine ophiolitic massif (Chenaillet massif, Hautes Alpes, France). Earth and Planetary Science Letters, 39, 98-108.

Morag, N., Avigad, D., Harlavan, Y., McWilliams, O., and Michard, A. (2008). Rapid exhumation and mountain building in the Western Alps: Petrology and 40Ar/39Ar geochronology of detritus from Tertiary basins of southeasern France. Tectonics, 27, doi:10.1029/2007TC002142.

O’Dogherty, L., Bill, M., Gorican, S., Dumitrica, P., and Masson, H. (2006). Bathonian radiolarians from an ophiolitic mélange of the Alpine Tethys (Gets Nappe, Swiss-French Alps). Micropaleontology, 51, $\mathrm{n}^{\circ}$ 6, 425-485.

Rüst, D. (1885). Beiträge zur Kenntniss der fossilen Radiolarien aus Gesteinen des Jura und der Kreide. Palaeontographica, 31, 269-321.

Schaaf, A., Polino, R. and Lagabrielle, Y. (1985). Nouvelle découverte de radiolaires d'âge Oxfordien supérieur-Kimméridgien inférieur à la base d'une série supra-ophiolitique des schistes lustrés piémontais (Massif de Traversiera, Haut Val Maïra, Italie). Comptes Rendus de l’Académie des Sciences, Paris, sér. II, 14, 1079-1084.

Schmid, S. M., Fügenschuh, B., Kissling, E., and Schuster, R. (2004). Tectonic map and overall architecture of the Alpine orogen. Eclogae Geologicae Helvetiae, 97, 93-117. 
518 Schwartz, S., Tricart, P., Guillot, S., Bernet, M., Chamorro-Perrez, E. M., Montagnac, G., and 519 Jourdan, S., in press. Source tracing of detrital serpentinite in the Oligocene molasse deposits 520 from the western Alps (Barrême basin): implications for relief formation in the internal zone.

521 Geological Magazine.

522

523 Seiders, V.M., and Blome, C.D. (1984). Clast compositions of Upper Mesozoic

524 conglomerates of the California Coast Ranges and their tectonic significance. In M.C. Blake

525 Jr. (ed.), Franciscan Geology of Northern California (pp. 135-148). Pacific Section of

526 Economic Paleontologists and Mineralogists 43.

527

528 Sissingh, W. (2001). Tectonostratigraphy of the West Alpine Foreland: correlation of Tertiary

529 sedimentary sequences, changes in eustatic sea-level and stress regimes. Tectonophysics, 333,

$530 \quad 361-400$.

531

532 Tricart, P. (1984). From passive margin to continental collision: a tectonic scenario for the

533 Western Alps. American Journal of Science, 284, 97-120.

534

535 Tricart, P., Amaudric du Chaffaut, S., Ayoub, C., Ballèvre, M., Caby, R., Gout, C.,

536 Lagabrielle, Y., Leblanc, D., Le Mer, O., Philippot, P., and Saby, P. (2003). Aiguilles-Col

537 Saint Martin Geological Map of France 1:50 000. Bureau de Recherches Géologiques et

538 Minières.

539 
540 Tricart, P., Lardeaux, J.-M., Schwartz, S., and Sue, C. (2006). The late extension in the inner

541 western Alps: a synthesis along the south-Pelvoux transect. Bulletin de la Société Géologique 542 de France, 177, 299-310.

543 


\section{Table and figures captions}

546 Table 1. Radiolarian contents of pebbles, biozones (UAZ) and ages (Baumgartner et al. 1995, 547 O’Dogherty et al. 2006). When available, UAZ range of each taxon is provided.

Fig. 1. Location map of southern French-Italian Alps (modified from Schmid et al. 2004).

550 Location of sampled molasse conglomerates: M, Montmaur, B, Barrême. Known sites with 551 in-situ bedrock fossiliferous radiolarites: P, Rocher de la Perdrix (Chenaillet Massif), C, 552 Cascavelier Peak (southern Queyras), T, Traversiera Massif. In red: major fault zones.

Fig. 2. Schematic stratigraphy of the Tertiary foreland series exposed in the French Subalpine zones, more specifically the Barrême basin. Barton. = Bartonian, Priabon. = Priabonian, Aquitan. = Aquitanian, conglo. $=$ conglomerate; biostr. $=$ biostrome The origin of Barrême basin pebbles are the Clumanc conglomerates.

Fig. 3. Outcrop of "Nagelfluh" molasse conglomerate near the village of Montmaur; circles: pebbles of red radiolarites.

561

562

Fig. 4. Middle and Late Jurassic radiolarians from Oligocene molasses chert pebbles

563 (Scanning Electron Microscope). For each microfossil: taxon, sample number, FC database

564 picture number, length of scale bar.

565 1- Pseudoeucyrtis sp., 7057-14, n 10, $260 \mu \mathrm{m}$.

566 2- Archeospongoprunum elegans Wu, 7057-22, $\mathrm{n}^{\circ} 13,150 \mu \mathrm{m}$.

567 3- Archeospongoprunum sp., 7057-E1, n 2, $250 \mu \mathrm{m}$.

568 4- Cinguloturris carpatica Dumitrica, 7057-14, n 11, $200 \mu \mathrm{m}$. 
5- Cinguloturris sp., 7057-22, $\mathrm{n}^{\circ}$ 6, $130 \mu \mathrm{m}$.

570 6- Archeodictyomitra apiarum (Rüst), 7057-14, n² 26, $200 \mu \mathrm{m}$.

571 7- Archeodictyomitra sp., 7057-14, n 28, $150 \mu \mathrm{m}$.

572 8- Archeodictyomitra sp., 7057-22, n² 20, $125 \mu \mathrm{m}$.

573 9- Archeodictyomitra sp., 7057-14, $\mathrm{n}^{\circ}$ 14, $150 \mu \mathrm{m}$.

574 10- ?Parvicingula mashitaensis Mizutani, 7057-14, n 4, $230 \mu \mathrm{m}$.

575 11- Parahsuum carpathicum Widz and De Wever, 7057-14, n 15, $150 \mu \mathrm{m}$.

576 12- Yaocapsa sp., 7057-15, n 4, $160 \mu \mathrm{m}$.

577 13- Protunuma sp., 7057-14, n 22, $140 \mu \mathrm{m}$.

578 14- ?Stichomitra sp., 7057-08, $\mathrm{n}^{\circ} 14,150 \mu \mathrm{m}$.

579 15- Pseudodictyomitrella cf. tuscanica Chiari, Cortese and Marcucci, 7057-22, nº 12, 100

$580 \mu \mathrm{m}$.

581 16- Zhamoidellum cf. argandi O'Dogherty, Gorican and Dumitrica, 7057-15, n 16, $130 \mu \mathrm{m}$.

582 17- Zhamoidellum ovum Dumitrica, 7057-14, n 19, $160 \mu \mathrm{m}$.

583 18- Stichocapsa aff. robusta, 7057-08, n 6, $150 \mu \mathrm{m}$.

584 19- Zhamoidellum sp., 7057-14, n² 27, $185 \mu \mathrm{m}$.

585 20- Pseudoristola tsunoensis (Aita), 7057-22, $\mathrm{n}^{\circ}$ 22, $110 \mu \mathrm{m}$.

586 21- Arcanicapsa cf. leiostraca (Foreman), 7057-22, n 3, $140 \mu \mathrm{m}$.

587 22- Zhamoidellum cf. calamin O'Dogherty, Gorican and Dumitrica, 7057-15, n 7, $120 \mu \mathrm{m}$.

588 23- Williriedellum sp. 1 (O'Dogherty et al. 2006), 7057-22, nº 9, $150 \mu \mathrm{m}$.

589 24- Podobursa cf. spinosa Ozvoldova, 7057-14, n 5, $200 \mu \mathrm{m}$.

590 25- ?Fultocapsa sp., 7057-22, n 23, $130 \mu \mathrm{m}$.

591 26- Acaeniotyle diaphorogona Foreman, 7057-14, nº 1, $200 \mu \mathrm{m}$.

592 27-Emiluvia cf. chica Foreman, 7057-22, n 15, $200 \mu \mathrm{m}$. 
593 28- Homoeoparonaella argolidensis Baumgartner, 7057-22, $\mathrm{n}^{\circ}$ 1, $200 \mu \mathrm{m}$.

594 29- Bernoullius cf. dicera (Baumgartner), 7057-20, n 6, $150 \mu \mathrm{m}$.

595 30- Tritrabs rhododactylus Baumgartner, 7057-22, nº 18, $200 \mu \mathrm{m}$.

596 31- Mirifusus sp., 7057-14, n³ 3, $250 \mu \mathrm{m}$.

597

598 Fig. 5. Crustal cross-section model proposing an evolution for the southern Western Alps 599 during the Early Oligocene. At that time, the Piemont thrust sheets already stacked in the 600 upper Cretaceous-Paleocene subduction accretionary wedge underwent severe syncollision 601 shortening. It resulted in a major orogenesis so that erosion fed abruptly the peripheral 602 molasses in margin-derived and ocean-derived clasts whose metamorphic signatures range 603 from non or very low-grade to high-grade blueschist facies (Lz: lizardite; Atg: antigorite). 


\begin{tabular}{|c|c|c|c|c|c|c|c|}
\hline \multirow[b]{2}{*}{ Radiolarian taxa } & \multicolumn{7}{|c|}{ Radiolarite peboles } \\
\hline & 7057-3 & 7057-15 & $7057-22$ & 7057-8 & $7057-20$ & 7064-E1 & 7057-14 \\
\hline Acaeniotyle diaphorogona Foreman $4-22$ & & & & & & & \begin{tabular}{|l}
$\mathrm{X}$ \\
\end{tabular} \\
\hline Arcanicapsa cf. leiostraca (Foreman) & & & $\mathrm{X}$ & & & & \\
\hline Archeodictyomitra apiarum (Rüst) 8-22 & & & & & $\mathrm{X}$ & $\mathrm{X}$ & $\mathrm{X}$ \\
\hline Archeodictyomitra sp. & & & $\mathrm{X}$ & & & & $\mathrm{X}$ \\
\hline Archeospongoprunum elegans Wu 6-? & & & $\bar{X}$ & & & & \\
\hline Archeospongoprunum cf. imlayi Pessagno & $\mathrm{X}$ & & & & & $\mathrm{X}$ & \\
\hline Bernoullius cf. dicera (Baumgartner) 3-10 & & & & & $\mathrm{X}$ & & \\
\hline Cinguloturris carpatica Dumitrica 7-11 & & $\mathrm{X}$ & $\mathrm{X}$ & $\mathrm{X}$ & & $\mathrm{X}$ & $\mathrm{X}$ \\
\hline Cinguloturris sp. & & & $\bar{X}$ & & & & \\
\hline Emiluvia ordinaria Ozvoldova 9-11 & & & & & & & $\mathrm{X}$ \\
\hline Emiluvia cf. chica Foreman 3-18 & & & $\mathrm{X}$ & & & & \\
\hline ?Fultocapsa sp. & & & $\mathrm{X}$ & & & & \\
\hline Homoeoparonaella argolidensis Baumgartner 4-11 & & & $\mathrm{X}$ & & & & \\
\hline Mirifusus sp. & & & $\mathrm{X}$ & & & & $\mathrm{X}$ \\
\hline Orbiculiformella sp. & $\mathrm{X}$ & & & & & & \\
\hline Parahsuum carpathicum Widz \& De Wever 7-11 & & & & & & & $\mathrm{X}$ \\
\hline ?Parvicingula mashitaensis Mizutani 8-15 & & & & & & & $\mathrm{X}$ \\
\hline Podobursa cf. spinosa Ozvoldova 8-13 & & & & & & & $\bar{x}$ \\
\hline Praeconocaryomma sp. & & & & $\mathrm{X}$ & $\mathrm{X}$ & & \\
\hline Protunuma sp. & & & & & & & $\mathrm{X}$ \\
\hline Pseudodictyomitrella cf. tuscanica Chiari, Cortese \& M & arcucci & & $\mathrm{X}$ & & & & \\
\hline Pseudoristola tsunoensis (Aita) 6-7 & & & $\bar{X}$ & & & & \\
\hline Pseudoeucyrtis sp. & & & & & & & $\bar{X}$ \\
\hline Stichocapsa robusta Matsuoka 5-7 & $\mathrm{X}$ & & & & & & \\
\hline Stichocapsa aff. robusta Matsuoka & & & & $\mathrm{X}$ & & & \\
\hline Stichocapsa sp. & $\mathrm{X}$ & & & & $\mathrm{X}$ & & \\
\hline ?Stichomitra sp. & & & & $\mathrm{X}$ & & & \\
\hline Tritrabs rhododactylus Baumgartner 3-13 & & & $\mathrm{X}$ & & & & \\
\hline Williriedellum sp. 1 (O'Dogherty et al. 2006) & & & $\mathrm{X}$ & & & & \\
\hline Yaocapsa sp. 5-6 & & $\mathrm{X}$ & & & & & \\
\hline Zhamoidellum ovum Dumitrica 9-11 & & & & & & & $\mathrm{X}$ \\
\hline Zham. cf. argandi O'Dogherty, Gorican \& Dumitrica 6- & & $\mathrm{X}$ & & & & & \\
\hline Zham. cf. calamin O'Dogherty, Gorican \& Dumitrica & & $\mathrm{X}$ & & & & & \\
\hline Zhamoidellum sp. & & & & & & & $\mathrm{X}$ \\
\hline Unitary Association Zones UAZ & $5-7$ & $6-7$ & 7 & $7-11$ & 8-?10 & 8-11 & $9-11$ \\
\hline Age ranges & \begin{tabular}{|l} 
Late \\
Baj. or \\
Early \\
Bath. to \\
Early \\
Call.
\end{tabular} & \begin{tabular}{|l|} 
Mid. \\
Bath. to \\
Early \\
Call. \\
\end{tabular} & \begin{tabular}{|l|} 
Late \\
Bath. to \\
Early \\
Call. \\
\end{tabular} & \begin{tabular}{|l|} 
Late \\
Bath. or \\
Early \\
Call. to \\
Late \\
Kim. or \\
Early \\
Tith. \\
\end{tabular} & \begin{tabular}{|l|} 
Mid \\
Call. to \\
? Early \\
Kim. \\
\end{tabular} & $\begin{array}{l}\text { Mid } \\
\text { Call. to } \\
\text { Late } \\
\text { Kim. or } \\
\text { Early } \\
\text { Tith. }\end{array}$ & $\begin{array}{l}\text { Mid } \\
\text { Oxf. to } \\
\text { Late } \\
\text { Kim. or } \\
\text { Early } \\
\text { Tith. }\end{array}$ \\
\hline
\end{tabular}

Table 1 


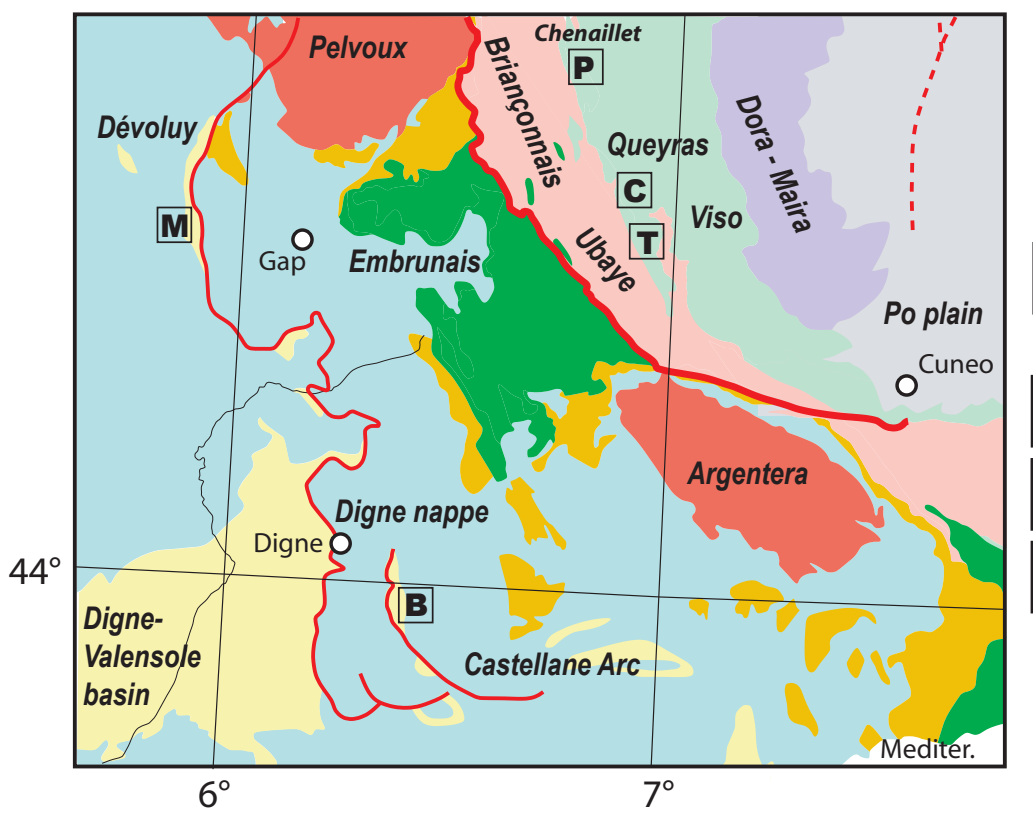

Digne front thrust

Briançonnais front thrust
EXTERNAL ZONE :

Pre-Tertiary sedimentary cover

Pre-Alpine basement

INTERNAL NON-METAMORPHIC ZONE :

Helminthoid flysch nappes ("exotic"flyschs) and associated basal tectonic slices

INTERNAL METAMORPHIC ZONES :

Briançonnais zone sensu lato (with associated Subbriançonnais units)

Piemont zone sensu lato

(ocean and distal margin derived units)

Pre-Alpine crystalline basement

\section{MAIN TERTIARY SYNOROGENIC BASINS}

Hinterland molasse

Paleoforeland deep sea turbidites

(External zone flysch, Paleogene )

Foreland and paleoforeland molasse

Fig. 1 


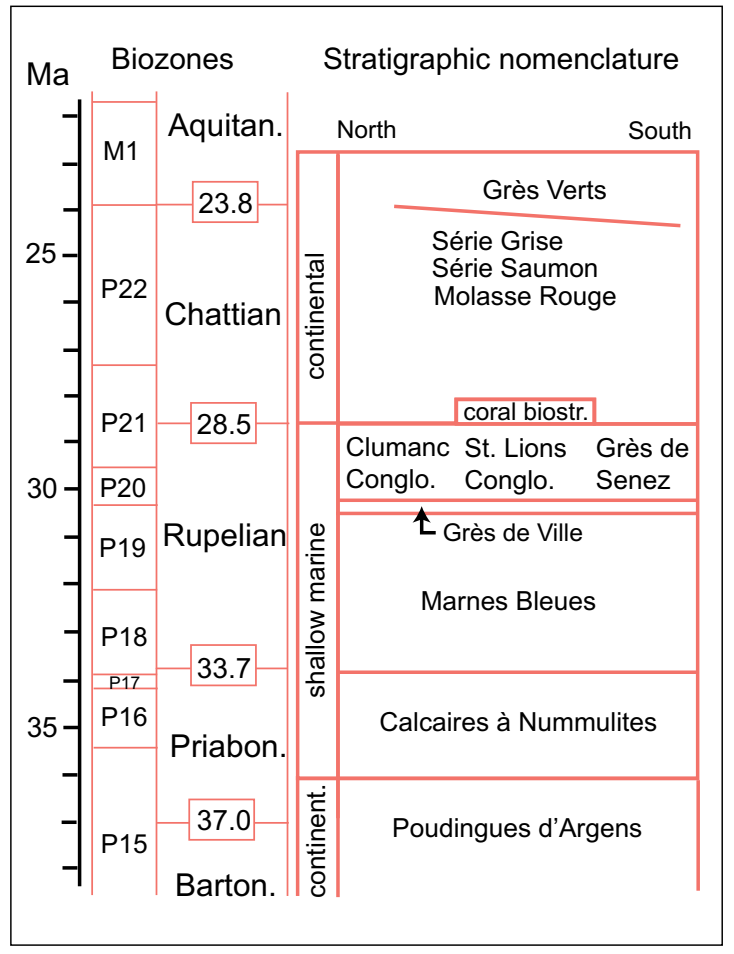

Fig. 2 


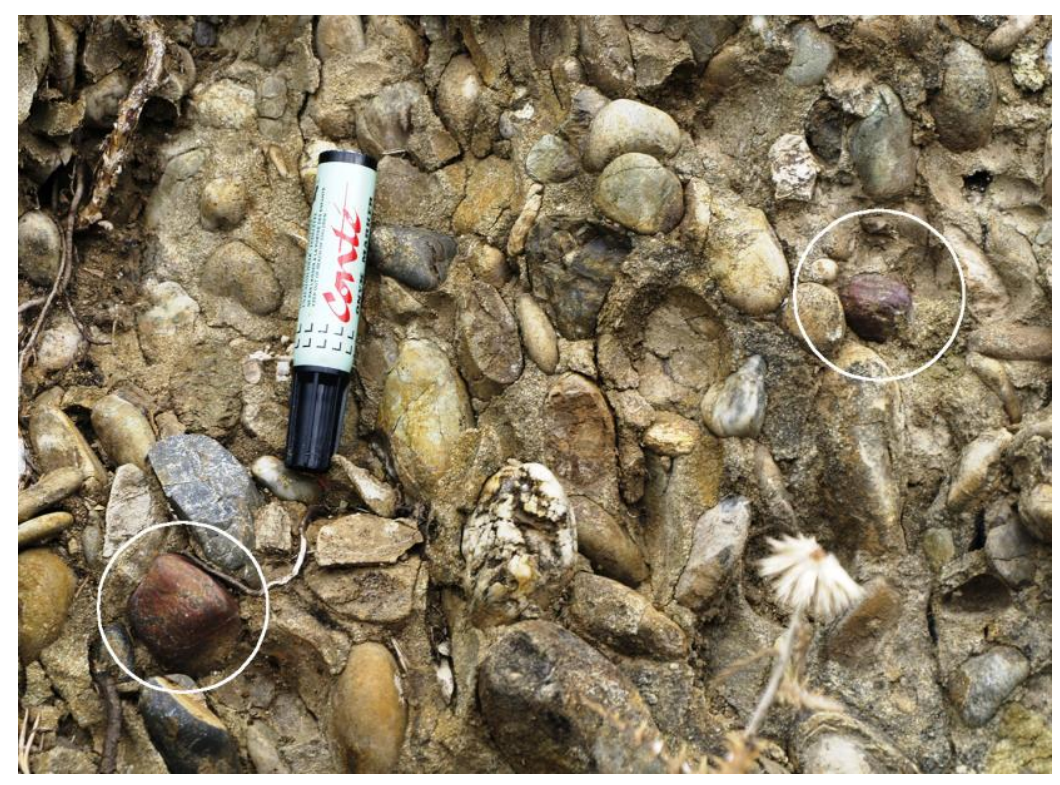

Fig. 3 


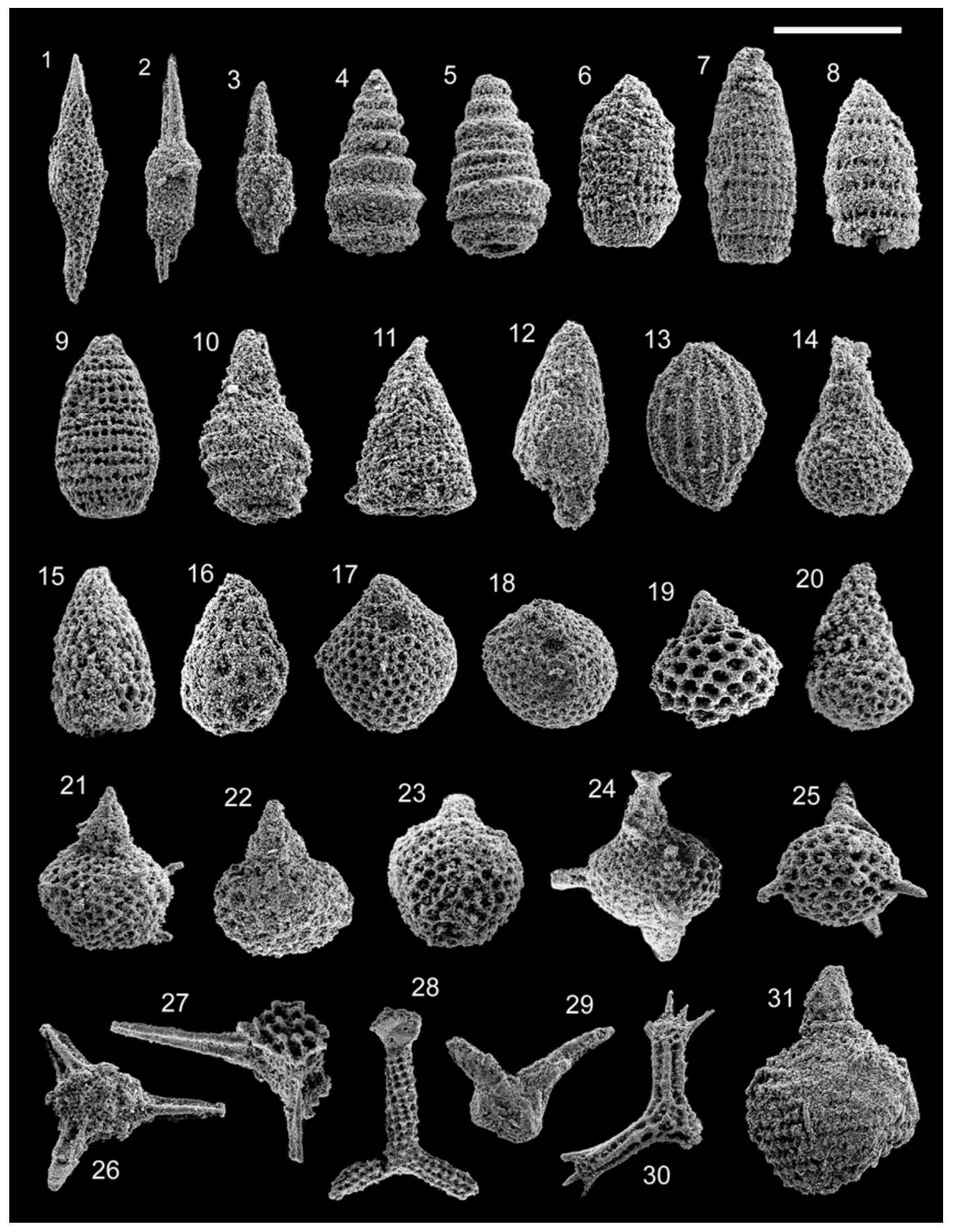

Fig. 4 


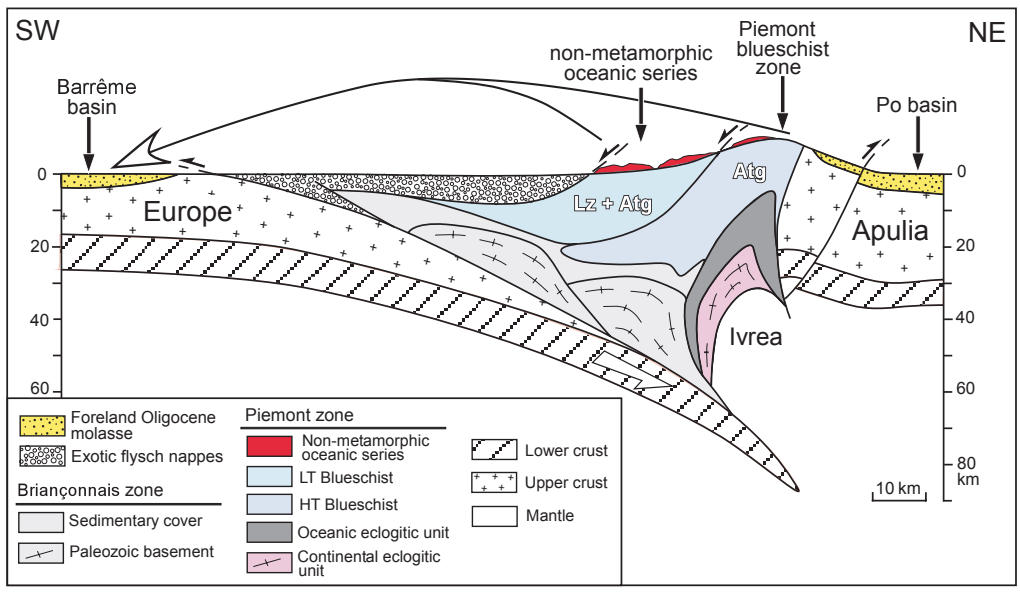

Fig. 5 